\title{
THE EFFECT OF FEMALE MANAGERS ON GENDER WAGE DIFFERENCES
}

\section{Veronika Hedija*}

\begin{abstract}
:
The paper is devoted to gender wage differences; it especially focuses on the impact of the gender characteristics of the manager on gender wage disparity. Under the social identity theory, women in managerial positions, that can affect the wage of their subordinates, are likely to evaluate female employees better than male employees. The purpose of this paper is to investigate the effect of the gender characteristics of middle managers on the wages of directly subordinated rank-and-file employees using a variation within the firm. We have used two methods to consider the effect of the manager gender characteristics on subordinates: the estimation of the wage function and the average treatment effect on the treated, both supplemented by a matching procedure. We concluded that women in middle management in comparison to their male counterparts have a lower tendency to apply wage discrimination against women. The presence of a female head of department led to a decrease in the gender pay gap by almost 7 percentage points.
\end{abstract}

Keywords: average treatment effect on the treated, gender pay gap, labour market, female managers, matching, wage differences

JEL Classification: J16, J24, J71

\section{Introduction}

The equal behaviour towards men and women and the right to receive equal compensation for the same or equivalent work belong to the basic rights as declared by the Treaty on the Functioning of the European Union and the Charter of Fundamental Rights of the European Union. Even though the condition of non-discrimination is anchored in legislature, differences in wages between men and women still exist in the countries of the European Union. Part of these wage differences can be attributed to the differences in personal or company characteristics of men and women. Part of the wage differences yet still remain unexplained and are usually attributed to the wage discrimination of women.

The gender wage differences and the trend in the gender pay gap are widely discussed in literature. The results of the studies show that in developed market economies the main cause for the existence of wage differences between men and women is the vertical and horizontal segregation (Oaxaca, 1973; Plantenga et al., 2006). The different characteristics of men and women cannot explain the entire wage difference and a part stays unexplained and is often attributed to the wage discrimination of women on the labour market. A large number of studies is dedicated to the proportion of women in management and the wage

* Veronika Hedija, Department of Economic Studies, College of Polytechnics, Jihlava, Czech Republic (veronika.hedija@vspj.cz). 
differences of men and women in managerial positions (Bertrand and Hallock, 2001; Jurajda and Paligorová, 2009).

A smaller number of papers analyses the issue of wage discrimination of women from the opposite angle. This does not look at the wage differences between men and women as such, but at the influence of the gender composition of the management and the existing gender wage differences. It analyses whether a larger number of women in managerial positions leads to a decrease in the gender wage difference or not. According to the social identity theory, individuals tend to favour members of their own group from other group members (Tajfel, 1982; Tajfel and Turner, 1979). Under this theory, women in managerial positions, that can affect the wage of their subordinates, are likely to evaluate female employees better than male employees. The vast majority of empirical studies confirms the negative impact of the higher proportion of men in the management on the female wage (Hultin and Szulkin, 1999 and 2003; Cohen and Huffman, 2007; Cardoso and Winter-Ebmer, 2010). And it is exactly this issue to which the following study is devoted.

The purpose of the paper is to consider the effect of the gender characteristics of middle managers on the wages of rank-and-file employees using a variation within a firm and to find out whether women in management show a lower tendency of using wage discrimination against women.

Our approach is different to that of the published studies, as none of these explore the influence of the gender characteristics of the middle management on the wages of direct subordinates using the direct link superior-subordinate on the level of individual companies. Our analysis uses data from two specific Czech hospitals, which are sited in the same town. We analyse the influence of the gender of the managers of the individual departments on the gender pay gap. In the study, the middle managers are the leaders of the individual departments in the hospitals and their positions and influence on the wages of their subordinates are fully comparable. This approach enables to minimise the distortion, which could result from a possible difference in the ranking of middle managers within a company and also when comparing individual companies from various sectors and their different influence on wage formation.

Our approach also differs in the focus on the public sector. The majority of authors engaging in this issue uses data from the private sector, the reason for this being that not only the managers in comparison to the public sector do have more freedom when determining the wage of their subordinates but also due to the fact that data for the public sector is not available. An exception is the study by Hultin and Szulkin (1999), where the authors used very small data set. The gender pay gap and also the influence of managers in determining the level of the wages of subordinates are lower in the public sector in comparison to the private sector, the reason for this being the regulation of wages, to which the wages in this sector are subject to. Our study provides the answer to the question, whether women in managerial positions have a tendency to a lower discrimination of women and whether this tendency also appears in the public sector, where there is generally less room for wage discrimination.

Considerable is also the contribution of the paper in the area of examination of the influence of the gender composition of management on the gender pay gap in the Czech Republic. To our knowledge, there are no previous studies that address this specific research question. 
The first section of the paper maps the existing knowledge in the area of the impact of female managers on the gender pay gap. The second and third sections describe the data set and methodology. To capture the effect of the gender characteristics of managers on the wage and gender wage difference of subordinates we used the administrative data from two Czech hospitals. This data covers information related to the individual departments of the hospitals, the gender characteristics of the heads of departments and allows a very detailed look at the problem. Two different methods are used. The linear regression model and the average treatment effect on the treated are estimated and both supplemented by a matching procedure. The fourth section presents the empirical results and the final section of the article summarizes the obtained results and compares these with the findings of the selected works dealing with the same issue.

\section{Gender Wage Differences: Results of the Selected Studies}

The studies of Hultin and Szulkin (1999, 2003), Cohen and Huffman (2007), Cardoso and Winter-Ebmer (2010) or Shin (2012) are devoted to the impact of the manager's gender on the gender wage differences.

Hultin and Szulkin (1999) studied the impact of the gender characteristics of the manager on the wage of subordinates in Sweden. They used two sets of data: the Swedish Level of Living Survey and the Swedish Establishment Survey 1991 and analyzed the data of 1,450 employees. They estimated the wage function of women and men using the proportion of men among managers and supervisors as one of the explanatory variables and specified the wage functions separately for the private and public sector. The authors concluded that the gender of managers and supervisors had a significant effect on the wages of women. The proportion of men among managers and supervisors affected women's earnings negatively. The negative effect of the proportion of male managers and supervisors was stronger in the private sector. This could be explained by more freedom in determining wages in the private sector where wages are not subject to wage regulations. In the study by Hultin and Szulkin (2003), the authors used a significantly broader sample of employees. They used an employer-employee matched data set covering a large number of Swedish private sector firms. They applied a multi-level model to estimate the effect of the proportion of male managers and supervisors on the gender wage gap and explored the impact separately for blue collar and white collar employees. Their results were similar to those of their previous study. They concluded that gender wage gaps are wider the larger the proportion of male representation among organizational managers and supervisors. In the final part of the study they distinguished between managers (high-level decision makers) and supervisors (lower-level decision makers) and examined the effect of the gender composition on the gender pay gap separately for these two groups of leaders. Due to data limitations, they did this analysis only on the blue-collar subsample. It concluded a stronger impact of gender composition of supervisors than of managers, this being due to their hierarchic distance from the employees.

Cohen and Huffman (2007) studied whether the gender characteristics of managers and the female managerial status affect inequality for the non-managerial workers beneath them using data from the 2000 U.S. Census. They used the three-level hierarchical linear model and as one of the explanatory variables the proportion of females in the management of the local industry. They identified managers as those in management 
occupations according to occupational classifications and used the index of net difference as the measurement of the female managerial status. The analysis suggested that the gender wage gap reduced with a greater representation of women in management. The impact of the gender characteristics of managers on the gender wage inequality was larger with the presence of high-status female managers.

Unlike Hultin and Szulkin (2003) and Cohen and Huffman (2007) we do not use as the explanatory variable the gender composition of managers but a dummy for the gender of the head of the department where the employee works. This approach matches the employee and the manager and allows to take into account the gender of the manager having a direct impact on the wage level.

The conclusions of the study by Cardoso and Winter-Ebmer (2010) are similar. The authors used data for Portugal and found that females profit from a female leading the firm. They estimated the Mincer-type female and male wage functions concentrating on the influence of the gender characteristics of the managers and reflecting the segregation of the workforce within the firms. Firms with more than a 50 per cent proportion of female owners (if this information was not available a similar procedure was used for top management or middle management) were classified as female-led firms. They concluded that women benefit more from higher wages in female-led firms than in male-led firms, as female leadership led to a reduction in the gender wage gap by 1.5 per cent, regardless of other characteristics. The impact of a female manager on the male and female wage is lower the higher the proportion of women in the firm.

Shin (2012) focused on the influence of female directors on the gender pay gap among executives in the United States of America. Using data from the Standard and Poor's ExecuComp database for 1998-2005, the hypothesis that women serving on the compensation committee are likely to evaluate female managers better when compared with the men on the compensation committee was evaluated. The empirical analysis supported this hypothesis. With an increase in the proportion of women on the compensation committee, the gender gap in executive compensation tended to reduce. But the gender pay gap in management did not depend on the gender of the chief executive officer. The presence of a female chief executive officer does not affect the compensation of female executives.

\section{Data}

The unexplained wage difference between men and women is evaluated in two Czech hospitals, which were willing to provide the necessary data. Both hospitals are located in the same town. The data comes from the year 2010 and is administrative. Employees with a long-term illness, on maternity or parental leave or working on a business agreement were excluded from the sample. The final data set covers the data of 8,662 employees, of which 1,636 are male and 7,026 female. 2,592 employees work in hospital 1 and 6,070 in hospital 2. In hospital 1, women represent about 77 per cent of employees and in hospital 2 almost 83 per cent.

In the hospitals the following characteristics of employees were measured: gender, age, highest level of education, occupation, number of years that the employee works in the hospital, working time (full-time means 1), department where the employee works, hours worked per year, overtime hours, days of sick leave, days of leave and annual gross wage. In the article, the hourly gross wage is used as the explained variable. This is calculated as a ratio of the annual gross wage (including bonuses) and the sum of worked hours (including overtime) and hours of annual leave (days of annual leave* $8 *$ working time). 
A very important factor when examining the impact of the manager's gender on wage discrimination against women is the wage setting-power of managers. The greater the manager's flexibility in wage formation, the larger the effect of the different approach towards the remuneration of male and female subordinates. The wage-setting power of the department heads was also analysed. Wages in the Czech public health sector are regulated by Government Regulation No. 564/2006 on the salaries of employees in public service and administration. It defines the wage classes and grades and assigns workers to these and sets the base gross wage for the individual classes and grades. The maximum amount of permitted bonuses is not regulated as is also the case in our hospitals where the amount of assigned bonuses is not regulated even by the internal regulation. This means that the final gross wage of an employee including bonuses depends on the decision of the head of department, who is limited by the Government Regulation, which regulates only the minimum wage, and by the size of the budget assigned to him. This implies that the leaders of departments have a relative flexibility in wage formation. Table 1 shows the average characteristics of men and women in the data set.

\section{Table 1}

\section{Average Characteristics of the Employees}

\begin{tabular}{|c|c|c|c|c|c|}
\hline Characteristic & $\begin{array}{c}\text { Mean } \\
\text { men }\end{array}$ & $\begin{array}{l}\text { Mean } \\
\text { women }\end{array}$ & Characteristic & $\begin{array}{c}\text { Mean } \\
\text { men }\end{array}$ & $\begin{array}{l}\text { Mean } \\
\text { women }\end{array}$ \\
\hline Hospital & & & Occupation & & \\
\hline - hospital 1 & 0.3570 & 0.2858 & - worker & 0.2451 & 0.0384 \\
\hline - hospital 2 & 0.6430 & 0.7142 & $\begin{array}{l}\text { - technical and } \\
\text { economic worker }\end{array}$ & 0.1131 & 0.0929 \\
\hline Age & 42.3753 & 39.4560 & - orderly & 0.1125 & 0.1073 \\
\hline Working time & 0.9053 & 0.9410 & - lower medical worker & 0.0128 & 0.0309 \\
\hline Years in firm & 9.4499 & 10.2542 & - paramedical worker & 0.0300 & 0.1110 \\
\hline Education & & & $\begin{array}{l}\text { - medical laboratory } \\
\text { technician }\end{array}$ & 0.0134 & 0.0575 \\
\hline - lower secondary & 0.0550 & 0.0511 & $\begin{array}{l}\text { - pharmaceutical } \\
\text { assistant }\end{array}$ & 0.0006 & 0.0108 \\
\hline $\begin{array}{l}\text { - upper secondary - } \\
\text { vocational without } \\
\text { certificate }\end{array}$ & 0.0018 & 0.0017 & - midwife & 0.0000 & 0.0238 \\
\hline $\begin{array}{l}\text { - upper secondary - } \\
\text { vocational certificate }\end{array}$ & 0.2213 & 0.0884 & - nurse & 0.0410 & 0.3877 \\
\hline $\begin{array}{l}\text { - upper secondary - school } \\
\text { diploma }\end{array}$ & 0.1767 & 0.5594 & - another professional & 0.0324 & 0.0253 \\
\hline $\begin{array}{l}\text { - tertiary-higher } \\
\text { professional education }\end{array}$ & 0.0306 & 0.0844 & - pharmacist & 0.0018 & 0.0051 \\
\hline - tertiary - bachelor level & 0.0159 & 0.0460 & - doctor & 0.3973 & 0.1092 \\
\hline $\begin{array}{l}\text { - tertiary - master and } \\
\text { doctoral level }\end{array}$ & 0.4988 & 0.1691 & Manager gender & & \\
\hline Sick leave & 14.4078 & 37.6560 & - male & 0.8527 & 0.8071 \\
\hline Overtime & 176.7223 & 58.5444 & - female & 0.1473 & 0.1929 \\
\hline
\end{tabular}


The women in the sample, when compared to the men, were in average younger, worked in the firm more years, reached a lower level of education, spent more time on sick leave and worked less overtime. The distribution of men and women by jobs was also very different. Men dominated the occupations worker and doctor, whilst women dominated as nurses.

The gender pay gap calculated as the difference between the logarithm of the average gross hourly earnings of the male employees and female employees was 0.14 (14 per cent). Women earned in average 87 per cent of the male wage. The gender pay gap reached 0.2597 (25.97 per cent) in hospital 1. In hospital 2 the gender pay gap was significantly lower and reached 0.1038 (10.38 per cent).

Table 2 shows the gender wage differences in the individual departments. The second and seventh column capture the gender pay gap calculated as the difference between the logarithm of the average gross hourly earnings of male employees and female employees in the individual departments. The third and eighth column show whether the head of department is male or female. The head being a man is shown as the number 0 , the head being a woman is shown as a 1 . The fourth and ninth column capture the percentage of female employees in the department and the fifth and tenth column the number of employees in the department.

\section{Table 2}

\section{Wage Differences in the Individual Departments}

\begin{tabular}{|c|c|c|c|c|c|c|c|c|c|}
\hline $\begin{array}{c}\text { Depart- } \\
\text { ment }\end{array}$ & GPG & Head & $\begin{array}{c}\text { Women } \\
\text { (\%) }\end{array}$ & $\begin{array}{c}\text { Emp- } \\
\text { loyees }\end{array}$ & $\begin{array}{c}\text { Depart- } \\
\text { ment }\end{array}$ & GPG & Head & $\begin{array}{c}\text { Women } \\
\text { (\%) }\end{array}$ & $\begin{array}{c}\text { Emp- } \\
\text { loyees }\end{array}$ \\
\hline \multicolumn{5}{|c|}{ Hospital 1 } & Dep 49 & -0.1279 & 1 & 95.00 & 80 \\
\hline Dep 1 & 0.2396 & 0 & 71.32 & 138 & Dep 50 & 0.4307 & 0 & 88.70 & 115 \\
\hline Dep 2 & 0.7852 & 0 & 95.45 & 46 & Dep 51 & 0.1613 & 1 & 83.10 & 142 \\
\hline Dep 3 & -0.3517 & 1 & 86.49 & 76 & Dep 52 & 0.3870 & 0 & 76.67 & 150 \\
\hline Dep 4 & -0.1826 & 1 & 45.16 & 64 & Dep 53 & 0.6341 & 0 & 84.80 & 125 \\
\hline Dep 5 & 0.0821 & 0 & 57.51 & 388 & Dep 54 & 0.3055 & 0 & 83.27 & 251 \\
\hline Dep 6 & - & 1 & 100 & 3 & Dep 55 & 0.5779 & 0 & 78.52 & 149 \\
\hline Dep 7 & 0.4953 & 0 & 78.31 & 251 & Dep 56 & 0.4418 & 0 & 84.21 & 57 \\
\hline Dep 8 & - & 1 & 100 & 20 & Dep 57 & 0.6969 & 0 & 86.36 & 66 \\
\hline Dep 9 & 0.6288 & 0 & 66.67 & 18 & Dep 58 & 0.1638 & 1 & 82.26 & 62 \\
\hline Dep 10 & 0.5376 & 0 & 85.50 & 338 & Dep 59 & 0.1320 & 0 & 93.48 & 46 \\
\hline Dep 11 & 0.3921 & 0 & 94.59 & 37 & Dep 60 & -0.1371 & 1 & 94.33 & 141 \\
\hline Dep 12 & - & 1 & 100 & 29 & Dep 61 & 0.3371 & 0 & 86.67 & 105 \\
\hline Dep 13 & 0.5022 & 0 & 86.49 & 37 & Dep 62 & 0.1861 & 0 & 65.22 & 23 \\
\hline Dep 14 & - & 1 & 100 & 2 & Dep 63 & 0.0358 & 0 & 99.11 & 112 \\
\hline Dep 15 & 0.0389 & 1 & 66.67 & 6 & Dep 64 & 0.3113 & 0 & 83.12 & 77 \\
\hline Dep 16 & 0.2263 & 0 & 89.89 & 89 & Dep 65 & -0.1980 & 1 & 93.55 & 93 \\
\hline Dep 17 & 0.5811 & 0 & 89.33 & 75 & Dep 66 & -0.0687 & 0 & 96.77 & 93 \\
\hline Dep 18 & 0.2028 & 0 & 83.33 & 12 & Dep 67 & 0.1712 & 0 & 89.61 & 77 \\
\hline
\end{tabular}


Table 2 - Continuation

\begin{tabular}{|c|c|c|c|c|c|c|c|c|c|}
\hline Dep 19 & 0.2504 & 0 & 58.57 & 70 & Dep 68 & 0.2990 & 0 & 75.21 & 117 \\
\hline Dep 20 & - & 1 & 100 & 17 & Dep 69 & 0.3189 & 1 & 99.14 & 116 \\
\hline Dep 21 & 0.2615 & 0 & 87.06 & 85 & Dep 70 & 0.2978 & 0 & 70.83 & 24 \\
\hline Dep 22 & 0.6451 & 0 & 92.68 & 41 & Dep 71 & 0.0419 & 1 & 88.46 & 26 \\
\hline Dep 23 & 0.4988 & 0 & 76.32 & 76 & Dep 72 & -0.0240 & 1 & 93.44 & 61 \\
\hline Dep 24 & 0.4825 & 0 & 83.90 & 118 & Dep 73 & -0.0396 & 0 & 81.55 & 103 \\
\hline Dep 25 & 0.3204 & 0 & 81.63 & 49 & Dep 74 & -0.4348 & 0 & 90.10 & 192 \\
\hline Dep 26 & 0.5381 & 0 & 79.44 & 107 & Dep 75 & 0.0240 & 1 & 85.71 & 14 \\
\hline Dep 27 & 0.0559 & 1 & 79.49 & 39 & Dep 76 & - & 1 & 100.00 & 6 \\
\hline Dep 28 & 0.4545 & 0 & 81.25 & 80 & Dep 77 & 0.3620 & 0 & 68.97 & 29 \\
\hline Dep 29 & 0.1481 & 0 & 60.87 & 46 & Dep 78 & -0.0138 & 0 & 85.53 & 76 \\
\hline Dep 30 & 0.2102 & 0 & 79.62 & 157 & Dep 79 & 0.4381 & 0 & 94.84 & 213 \\
\hline Dep 31 & 0.5667 & 0 & 85.51 & 69 & Dep 80 & 0.2457 & 1 & 94.00 & 50 \\
\hline Dep 32 & 0.4480 & 0 & 77.78 & 9 & Dep 81 & 0.0468 & 1 & 96.05 & 76 \\
\hline \multicolumn{5}{|c|}{ Hospital 2} & Dep 82 & 0.2754 & 1 & 82.35 & 34 \\
\hline Dep 33 & -0.1215 & 1 & 60.00 & 5 & Dep 83 & 0.3567 & 0 & 29.57 & 115 \\
\hline Dep 34 & 0.3870 & 0 & 60.00 & 10 & Dep 84 & 0.2032 & 0 & 92.31 & 39 \\
\hline Dep 35 & - & 1 & 100.00 & 3 & Dep 85 & 0.5708 & 0 & 97.22 & 36 \\
\hline Dep 36 & - & 0 & 100.00 & 9 & Dep 86 & 0.6814 & 0 & 89.58 & 96 \\
\hline Dep 37 & -0.0516 & 1 & 67.41 & 135 & Dep 87 & 0.1380 & 1 & 76.92 & 52 \\
\hline Dep 38 & -0.0541 & 1 & 94.23 & 52 & Dep 88 & -0.0325 & 0 & 97.10 & 138 \\
\hline Dep 39 & 0.2006 & 0 & 38.91 & 550 & Dep 89 & -0.1086 & 0 & 95.65 & 23 \\
\hline Dep 40 & 0.2785 & 0 & 90.10 & 101 & Dep 90 & 0.4728 & 0 & 94.29 & 70 \\
\hline Dep 41 & - & 0 & 100.00 & 11 & Dep 91 & -0.0166 & 0 & 97.06 & 34 \\
\hline Dep 42 & -0.1321 & 1 & 27.27 & 44 & Dep 92 & 0.3499 & 0 & 88.49 & 252 \\
\hline Dep 43 & 0.3330 & 1 & 73.68 & 19 & Dep 93 & 0.3776 & 0 & 97.08 & 171 \\
\hline Dep 44 & 0.3041 & 0 & 76.38 & 199 & Dep 94 & 0.1683 & 0 & 92.86 & 14 \\
\hline Dep 45 & 0.1298 & 0 & 86.84 & 266 & Dep 95 & -0.0495 & 1 & 95.83 & 24 \\
\hline Dep 46 & 0.4065 & 0 & 91.19 & 159 & Dep 96 & -0.8087 & 0 & 95.83 & 24 \\
\hline Dep 47 & 0.1005 & 0 & 92.66 & 109 & Dep 97 & 0.8544 & 0 & 78.85 & 104 \\
\hline Dep 48 & 0.0489 & 1 & 88.57 & 105 & & & & & \\
\hline
\end{tabular}

Women led 32 per cent of the departments. They headed eight departments in hospital 1 and twenty two departments in hospital 2. Women in leadership dominated in the departments with less than 10 employees. They led 75 per cent of these departments. In the departments with 10-19 employees, women led 37.5 per cent of these departments, in the departments with 20-49 employees 32 per cent, between 50-99 employees 40 per cent. Only 15 per cent of managers were women in the departments with 100 and more employees. Women predominantly led the smaller departments. 
With regards to the gender constitution of the female-headed departments, in 55 per cent of the female-headed departments there were more than 90 per cent of female employees and 41 per cent of these departments consisted only of female employees. In comparison, only in 33 per cent of the male-headed departments were there more than 90 per cent of female employees, and 9 per cent of these had only female employees (excluding the manager). This means that women led a higher percentage of departments with a larger proportion of women.

These results are in the line with the general findings in the Czech Republic, showing that the ratio of female managers is higher in the lower level of management and in areas with a larger proportion of female employees (Vlach et al., 2008).

The gender pay gap was higher in the departments with a larger proportion of women employees and in the male-headed departments. This fact is illustrated in Figure 1 and Figure 2. The departments are sorted according to the ratio of women in the departments. The gender pay gaps in the women-headed departments are black, the men-headed departments white.

\section{Figure 1}

Gender Pay Gaps in the Individual Departments (20-80 per cent of women)

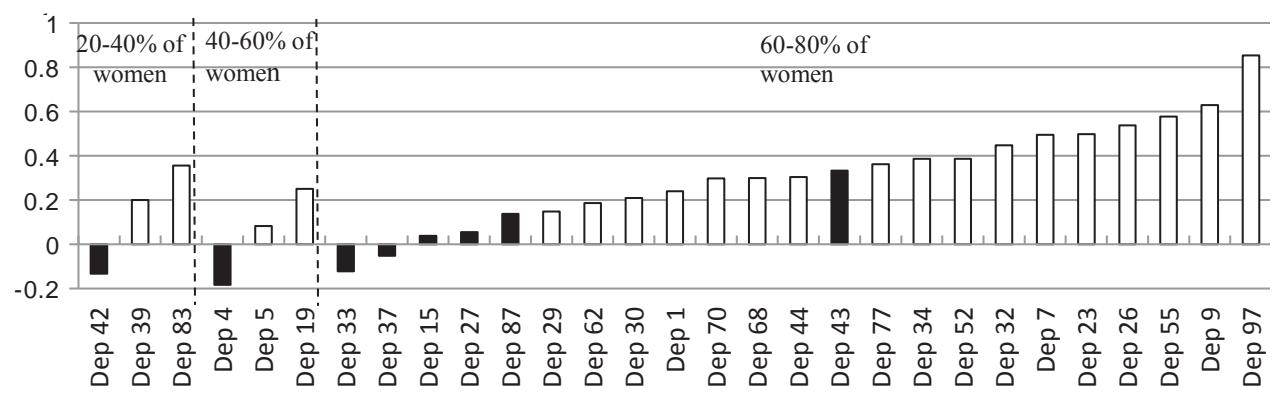

Note: Women-headed departments are black, men-headed departments are white.

Figure 2

Gender Pay Gap in the Individual Departments (80-99.9 per cent of women)

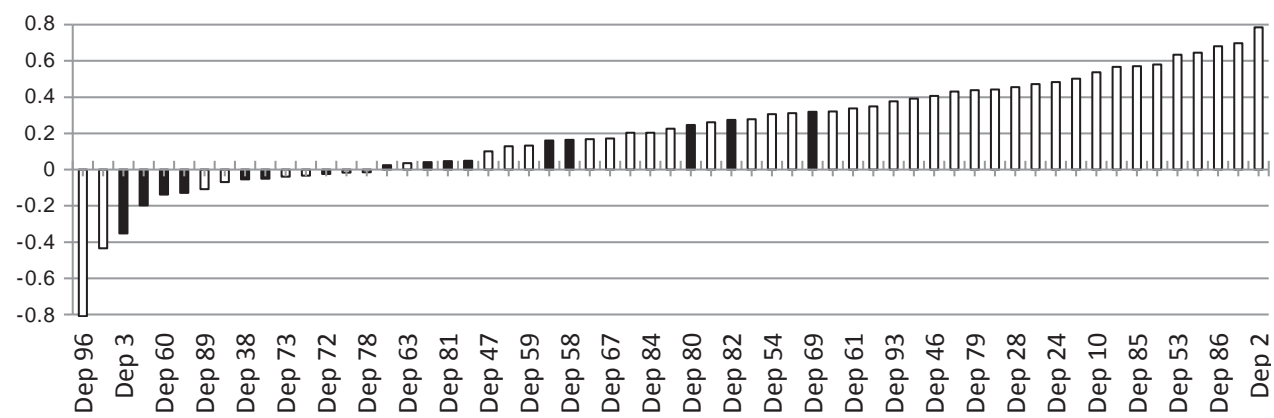

Note: Women-headed departments are black, men-headed departments are white. 
The above data is very raw and rather indicative. It tells us only very little about the potential discrimination of women or men in the individual departments and the lower tendency of women managers to implement wage discrimination against women. It is probable that the existing gender wage differences or their part could be explained by the different characteristics of men and women in these departments.

\section{Methodology}

Several methods can be used to estimate the degree of the wage differences between men and women, which cannot be explained by the different characteristics of these. The simplest methods include the estimation of the wage function of the employees, where gender is one of the explanatory variables. A well-known and frequently used method is the OaxacaBlinder decomposition (Oaxaca, 1973; Blinder, 1973), which allows a decomposition of the gender pay gap into two parts. One is known as the endowment effect, and it is the part of gender pay gap which can be explained by the different characteristics of men and women. The latter part is the one, which stays unexplained. This part of the gender pay gap is often called the remuneration effect or the effect of discrimination and in the language of 'treatment literature' we can mark this as the casual effect or the better average treatment effect on the treated (ATT). We use both of the noted methods.

\section{Wage function estimation}

To estimate the impact of the gender characteristics of middle managers on subordinates and the gender pay gap we estimate the Mincer-type wage function where one of the explanatory variables would be the gender, the gender of the manager and their interaction.

We use the linear regression model to estimate the coefficient of the wage function

$$
y=\alpha+\beta_{1} \cdot \text { man }+\beta_{2} . \text { man.femalemanager }+\beta_{3} . \text { female manager }+\gamma \cdot X+u .
$$

Where $y$ is the logarithm of the gross hourly wages, man is the dummy for male employees, female manager is the dummy for the female led departments, $X$ is the vector of the selected personal and department's characteristics of the employees and $u$ is a disturbance term.

To capture the gender pay gap and the effect of the female managers on the wage and gender pay gap, we use a dummy for gender, a dummy for the manager's gender and interaction between these two as explanatory variables. Man is the male dummy, female manager is the dummy for the female head of department. An interaction of the man and female manager dummy enables to measure the effect of the female managers on the wages of men relative to the wages of women.

Selected personal and department characteristics are used as other explanatory variables: age, age squared, years in the company, dummy for education, dummy for occupation, working times, overtime and sick leave and dummy for departments.

In accordance to the Mincer wage function (Mincer, 1973), a higher level of education and greater potential experience result in a higher wage. The explanatory variables age, age squared, years in the company and working time represent the potential experience of the employee. Age is the age of the employee in years, years in the company is the number of years the employee has been working in the hospital. Working time denotes the working 
time of the employee in the hospital, where 1 is full-time and stands for 40 hours per week. Education represents the highest level of attained education. Dummy variables are used where seven stages of education are distinguished: lower secondary, upper secondary vocational education without certificate, upper secondary with vocational certificate, upper secondary with school diploma, tertiary higher professional education, bachelor level of tertiary education and master and doctoral level. Empirical studies confirm that occupation is one of the important determinants of the wage level (Jurajda, 2005, Stupnytskyy, 2007). Due to this, occupation is used as one of the explanatory variables. Occupation is a dummy variable where employees are divided into twelve groups: worker, technical and economic worker, orderly, lower medical worker, paramedical worker, medical laboratory technician, pharmaceutical assistant, midwife, nurse, other professional, pharmacist and doctor. The other explanatory variable is overtime. It denotes the number of hours which the employee works overtime. This is used as an explanatory variable due to the bonuses for overtime. More overtime hours result in a higher hourly wage. The explanatory variable sick leave represents the number of days which employees spent on sick leave. The more days spent on sick leave result in lower benefits and a lower hourly gross wage. To capture the potential wage differences among the individual departments, the dummy for the departments is used as an explanatory variable. There are altogether 97 departments in both hospitals.

To minimize the model's dependence and to receive more accurate results, we use matching as the pre-processing procedure as proposed (Ho et al., 2007). The aim of the matching procedure is to create a sample of men and women, which is as homogeneous as possible. The matching procedure has also some weaknesses. It gives evidence only about the wage differences in the occupations, which are represented by both the male and female gender, and this must be taken into account when interpreting the results.

There are more matching methods: one-to-one matching, exact matching, propensity score matching, monotonic imbalance bounding. In this case we use coarsened exact matching and nearest neighbour matching. ${ }^{1}$ The main idea of coarsened exact matching is to coarsen the variables into groups, and then to apply exact matching. This results in the original values of the matched data being retained. Besides using coarsened exact matching, we also apply nearest neighbour matching for comparison, allowing us to use a larger sample of employees. Nearest neighbour matching is based on propensity score matching. It matches women and men which are closest in terms of the propensity score. We use matching without replacement, where the analysed individuals can be used just once, to maintain the greatest sample of employees (Iacus et al., 2012). Both methods are available using the freely available programme MatchIt (see Ho et al., 2007).

\section{Average treatment effect on the treated}

The other method we use to find out the effect of the gender characteristics of the managers on the gender wage differences is the estimation of the average treatment effect on the treated. This method enables to determine the part of the gender pay gap which cannot be explained by the different characteristics of men and women. 'The average treatment effect on the treated is the mean effect for those who actually participated in the program'.

1 We tried to use exact matching but this produced very few matches. 
(Wooldridge, 2002, p. 605) In our case the ATT is the mean effect for women in the form of a lower wage due to them being women. We use it in this way to estimate the unexplained part of the gender pay gap in our hospitals.

We use the following formula for the calculation of the average treatment effect on the treated

$$
A T T=E\left(y_{1}-y_{0} \mid w=1\right) .
$$

Where $\mathrm{w}$ is the binary treatment indicator, $w=1$ denotes treatment and $w=0$ otherwise, $y_{1}$ is the potential outcome with treatment and $y_{0}$ is the potential outcome without treatment. In our case, to be treated means to be a woman. The ATT can be rewritten as

$$
A T T=E\left(y_{1} \mid w=1\right)-E\left(y_{0} \mid w=1\right) .
$$

Where ATT represents the gender pay gap, which cannot be explained by the different characteristics of men and women i.e. the remuneration effect in the language of the Oaxaca-Blinder decomposition. The term is the sample average of the logarithm of the gross hourly wage of women and the term is the sample average of the logarithm of the gross hourly wage of women, if they were men. It seems to be very easy to compute the ATT but in reality only one of the right-side terms is known. From our sample, we can compute the first term on the right-side of equation 3. The second term, the average of the logarithm of the gross hourly wage of women if they were men, has to be estimated in some way. There are more ways to estimate this. For more details see Wooldridge (2002) and Ho et al. (2007). We estimate this using the regression model and using simulation.

First, we estimate the coefficient of the wage function of men from the regression model.

$$
y_{0}=\beta_{0} \cdot X_{0}+u
$$

Where, $\gamma_{0}$ is the logarithm of the male gross hourly wage, $\beta_{0}$ is the vector of the coefficients of the wage function, $X_{0}$ is the vector of the chosen characteristics of men and $u$ is a disturbance term.

We then use the estimated coefficients of the male wage function to compute the average wage of women, if they were men. To reduce the estimation and fundamental uncertainty we use simulation of estimating the parameters of the wage function and stochastic component working with thousand simulations. The first step involves estimating the parameters, the second step the simulation of the random component for all versions of parameters. (King et al., 2000)

$$
E\left(y_{0} \mid X, w=1\right)=E\left(\beta_{0} . X_{1 i}\right)
$$

Where $E\left(\beta_{0} \cdot X_{1 i}\right)$ is the mean of the predicted wage of every woman in the sample after the simulation. Finally, we estimate the average treatment effect on the treated.

$$
A T T=E\left(y_{1} \mid w=1\right)-E\left(\beta_{0} \cdot X_{1 i}\right) .
$$

In this case, the ATT expresses the unexplained part of the gender pay gap. We must be careful as the obtained results can be biased. If the characteristics of the treated and the control groups are too different, the coefficient of the women wage function will probably 
be far enough from the coefficients of the hypothetical wage function of men. To reduce bias and model dependence, we used here matching as a pre-processing procedure as proposed Ho et al. (2007).

To find out whether the wage differences vary by hospital departments and whether the amount of the unexplained wage gap depends in some way on the gender of the department head, we estimate the ATT (equation 6) separately for the departments controlled by men and women. Firstly, the ATT is stated without matching. Then we use coarsened exact matching and nearest neighbour matching for comparison.

\section{Empirical Results}

\section{Wage function estimation}

To capture the effect the female managers on the wages of female and male subordinates, we estimated the wage function from equation 1 using dummy for man, dummy for female managers and an interaction of these. To estimate the coefficients of wage function we used the OLS method. Table 3 shows the results.

Table 3

Wage Function

\begin{tabular}{|c|c|c|c|}
\hline & Without matching & $\begin{array}{c}\text { Nearest neighbour } \\
\text { matching }\end{array}$ & $\begin{array}{c}\text { Coarsened exact } \\
\text { matching }\end{array}$ \\
\hline Constant & $\begin{array}{c}3.4090^{* * *} \\
(0.0421)\end{array}$ & $\begin{array}{c}3.3160^{* * *} \\
(0.0759)\end{array}$ & $\begin{array}{c}3.3680^{* * *} \\
(0.2071)\end{array}$ \\
\hline Man & $\begin{array}{c}0.1221^{* * * *} \\
(0.0076)\end{array}$ & $\begin{array}{c}0.1240^{* * *} \\
(0.0097)\end{array}$ & $\begin{array}{c}0.1009^{* * *} \\
(0.0161)\end{array}$ \\
\hline Female manager $x$ man & $\begin{array}{c}-0.0618^{* * *} \\
(0.0176)\end{array}$ & $\begin{array}{l}-0.0450^{*} \\
(0.0238)\end{array}$ & $\begin{array}{l}-0.0543 \\
(0.0490)\end{array}$ \\
\hline Female manager & $\begin{array}{c}0.0568 \\
(0.0457)\end{array}$ & $\begin{array}{l}0.0652 \\
(0.1412)\end{array}$ & $\begin{array}{l}-0.0945 \\
(0.1473)\end{array}$ \\
\hline Age & $\begin{array}{c}0.0312^{* * *} \\
(0.0015)\end{array}$ & $\begin{array}{l}0.0373^{* * *} \\
(0.0028)\end{array}$ & $\begin{array}{c}0.0386^{* * *} \\
(0.0071)\end{array}$ \\
\hline Age squared & $\begin{array}{c}-0.0003^{* * *} \\
(0.0000)\end{array}$ & $\begin{array}{c}-0.0003^{* * *} \\
(0.0000)\end{array}$ & $\begin{array}{l}-0.0004^{* * *} \\
(0.0001)\end{array}$ \\
\hline Working time & $\begin{array}{l}-0.0595^{* * *} \\
(0.0129)\end{array}$ & $\begin{array}{c}-0.0932^{* * *} \\
(0.0215)\end{array}$ & $\begin{array}{l}-0.0742 \\
(0.0792)\end{array}$ \\
\hline Years in firm & $\begin{array}{c}0.0081 * * * \\
(0.0004)\end{array}$ & $\begin{array}{c}0.0103 * * * \\
(0.0007)\end{array}$ & $\begin{array}{c}0.0144^{* * *} \\
(0.0020)\end{array}$ \\
\hline \multicolumn{4}{|c|}{ Occupation } \\
\hline $\begin{array}{l}\text { - technical and economic } \\
\text { worker }\end{array}$ & $\begin{array}{l}0.3209^{* * *} \\
(0.0175)\end{array}$ & $\begin{array}{l}0.3542^{* * *} \\
(0.0240)\end{array}$ & $\begin{array}{c}0.2711^{* * *} \\
(0.0501)\end{array}$ \\
\hline - orderly & $\begin{array}{c}0.1946^{* * * *} \\
(0.0198)\end{array}$ & $\begin{array}{c}0.1048^{* * *} \\
(0.0349)\end{array}$ & $\begin{array}{c}0.0598 \\
(0.1294)\end{array}$ \\
\hline - lower medical worker & $\begin{array}{c}0.5765^{* * *} \\
(0.0244)\end{array}$ & $\begin{array}{c}0.4810^{* * *} \\
(0.0482)\end{array}$ & $\begin{array}{c}0.4574^{* * *} \\
(0.1359)\end{array}$ \\
\hline - paramedical worker & $\begin{array}{c}0.6565 * * * \\
(0.0232)\end{array}$ & $\begin{array}{c}0.4741 * * * \\
(0.0438)\end{array}$ & $\begin{array}{l}0.3347^{*} \\
(0.1730)\end{array}$ \\
\hline
\end{tabular}


Table3 - Continuation

\begin{tabular}{|c|c|c|c|}
\hline $\begin{array}{l}\text { - medical laboratory } \\
\text { technician }\end{array}$ & $\begin{array}{c}0.6309 * * * \\
(0.0247)\end{array}$ & $\begin{array}{c}0.5179 * * * \\
(0.0525)\end{array}$ & $\begin{array}{c}0.3207 \\
(0.2165)\end{array}$ \\
\hline - pharmaceutical assistant & $\begin{array}{c}0.5197^{* * *} \\
(0.0397)\end{array}$ & $\begin{array}{c}0.4382^{* * *} \\
(0.1458)\end{array}$ & $\begin{array}{l}-0.0115 \\
(0.1891)\end{array}$ \\
\hline - midwife & $\begin{array}{c}0.5691 \\
(0.0309)\end{array}$ & - & - \\
\hline - nurse & $\begin{array}{c}0.7058^{* * *} \\
(0.0214)\end{array}$ & $\begin{array}{c}0.5690 * * * \\
(0.0416)\end{array}$ & $\begin{array}{c}0.4714^{* * *} \\
(0.1331)\end{array}$ \\
\hline - other professional & $\begin{array}{c}0.6117^{* * * *} \\
(0.0280)\end{array}$ & $\begin{array}{c}0.5048^{* * *} \\
(0.0447)\end{array}$ & $\begin{array}{c}0.1191 \\
(0.1436)\end{array}$ \\
\hline - pharmacist & $\begin{array}{c}0.7945^{* * *} \\
(0.0495)\end{array}$ & $\begin{array}{c}0.6680^{* * *} \\
(0.1112)\end{array}$ & $\begin{array}{c}0.3728 \\
(0.2301)\end{array}$ \\
\hline - doctor & $\begin{array}{c}0.7575^{* * *} \\
(0.0251)\end{array}$ & $\begin{array}{c}0.6550^{* * *} \\
(0.0402)\end{array}$ & $\begin{array}{c}0.2113 \\
(0.1290)\end{array}$ \\
\hline \multicolumn{4}{|c|}{ Education } \\
\hline $\begin{array}{l}\text { - upper secondary - } \\
\text { vocational without } \\
\text { certificate }\end{array}$ & $\begin{array}{l}-0.0850 \\
(0.0548)\end{array}$ & $\begin{array}{l}-0.0061 \\
(0.1078)\end{array}$ & - \\
\hline $\begin{array}{l}\text { - upper secondary - } \\
\text { vocational certificate }\end{array}$ & $\begin{array}{c}0.0354^{* * *} \\
(0.0120)\end{array}$ & $\begin{array}{l}0.0356^{*} \\
(0.0199)\end{array}$ & $\begin{array}{c}0.0699 \\
(0.0426)\end{array}$ \\
\hline $\begin{array}{l}\text { - upper secondary - school } \\
\text { diploma }\end{array}$ & $\begin{array}{c}0.1003^{* * *} \\
(0.0141)\end{array}$ & $\begin{array}{c}0.0698^{* * *} \\
(0.0232)\end{array}$ & $\begin{array}{c}0.1666^{* * *} \\
(0.0550)\end{array}$ \\
\hline $\begin{array}{l}\text { - tertiary - higher } \\
\text { professional education }\end{array}$ & $\begin{array}{c}0.1276^{* * *} \\
(0.0170)\end{array}$ & $\begin{array}{c}0.1299 * * * \\
(0.0362)\end{array}$ & $\begin{array}{c}0.1947^{* * *} \\
(0.0690)\end{array}$ \\
\hline - tertiary - bachelor level & $\begin{array}{c}0.1466^{* * *} \\
(0.0185)\end{array}$ & $\begin{array}{c}0.1690 * * * \\
(0.0414)\end{array}$ & $\begin{array}{c}0.2318^{* * *} \\
(0.0852)\end{array}$ \\
\hline $\begin{array}{l}\text { - tertiary - master and } \\
\text { doctoral level }\end{array}$ & $\begin{array}{l}0.2729^{* * *} \\
(0.0185)\end{array}$ & $\begin{array}{c}0.2886^{* * *} \\
(0.0308)\end{array}$ & $\begin{array}{c}0.4923^{* * *} \\
(0.0683)\end{array}$ \\
\hline Overtime & $\begin{array}{l}0.0004^{* * *} \\
(0.0000)\end{array}$ & $\begin{array}{c}0.0003^{* * *} \\
(0.0000)\end{array}$ & $\begin{array}{c}0.0004^{* * *} \\
(0.0001)\end{array}$ \\
\hline Sick leave & $\begin{array}{c}0.00002 \\
(0.00002)\end{array}$ & $\begin{array}{l}-0.00002 \\
(0.00006)\end{array}$ & $\begin{array}{c}0.0001 \\
(0.0003)\end{array}$ \\
\hline Department fixed effects & Yes & Yes & Yes \\
\hline $\mathbf{R}^{2}$ & 0.7078 & 0.758 & 0.7457 \\
\hline $\mathbf{N}$ & 8,662 & 3,272 & 671 \\
\hline
\end{tabular}

***significant at the 1 per cent level, **significant at the 5 per cent level, *significant at the 10 per cent level, standard error in brackets

The second column of Table 3 shows the estimated coefficients of the wage function. The unexplained gender pay gap was 0.1221 . This means that being a man increased the earnings of the employee by about 12.2 per cent. The impact of the female gender manager characteristics on the wage of subordinates was 0.0567 and on the wage of male relative to female subordinates -0.0618 . This means that having a female head of department caused a decrease in the gender pay gap by 6.18 percentage points. 
Table 4

Average Characteristics of Men and Women after Matching

\begin{tabular}{|c|c|c|c|c|}
\hline \multirow[b]{2}{*}{ Characteristics } & \multicolumn{2}{|c|}{ Nearest neighbour matching } & \multicolumn{2}{|c|}{ Coarsened exact matching } \\
\hline & Mean men & Mean women & Mean men & Mean women \\
\hline \multicolumn{5}{|c|}{ Hospital } \\
\hline - hospital 1 & 0.3570 & 0.3240 & 0.3401 & 0.3183 \\
\hline - hospital 2 & 0.6430 & 0.6760 & 0.6599 & 0.6817 \\
\hline Age & 42.3753 & 41.2072 & 39.5306 & 36.0345 \\
\hline Working time & 0.9054 & 0.8992 & 0.9538 & 0.9634 \\
\hline Years in firm & 9.4501 & 8.9689 & 6.4336 & 5.5754 \\
\hline \multicolumn{5}{|c|}{ Education } \\
\hline - lower secondary & 0.0550 & 0.0617 & 0.0408 & 0.0398 \\
\hline $\begin{array}{l}\text { - upper secondary - vocational } \\
\text { without certificate }\end{array}$ & 0.0018 & 0.0012 & 0.0000 & 0.0000 \\
\hline $\begin{array}{l}\text { - upper secondary - vocational } \\
\text { certificate }\end{array}$ & 0.2213 & 0.1852 & 0.2993 & 0.2387 \\
\hline $\begin{array}{l}\text { - upper secondary - school } \\
\text { diploma }\end{array}$ & 0.1767 & 0.2249 & 0.2313 & 0.3156 \\
\hline $\begin{array}{l}\text { - tertiary - higher professional } \\
\text { education }\end{array}$ & 0.0306 & 0.0306 & 0.0544 & 0.0849 \\
\hline - tertiary - bachelor level & 0.0159 & 0.0183 & 0.0170 & 0.0318 \\
\hline $\begin{array}{l}\text { - tertiary - master and doctoral } \\
\text { level }\end{array}$ & 0.4988 & 0.4780 & 0.3571 & 0.2891 \\
\hline Sick leave & 14.4078 & 20.3203 & 7.8605 & 9.9363 \\
\hline \multicolumn{5}{|c|}{ Occupation } \\
\hline - worker & 0.2451 & 0.1608 & 0.3367 & 0.2679 \\
\hline - technical and economic worker & 0.1131 & 0.1339 & 0.1293 & 0.1194 \\
\hline - orderly & 0.1125 & 0.1522 & 0.0578 & 0.0451 \\
\hline - lower medical worker & 0.0128 & 0.0202 & 0.0272 & 0.0902 \\
\hline - paramedical worker & 0.0300 & 0.0434 & 0.0340 & 0.0451 \\
\hline - medical laboratory technician & 0.0134 & 0.0214 & 0.0136 & 0.0133 \\
\hline - pharmaceutical assistant & 0.0006 & 0.0012 & 0.0034 & 0.0053 \\
\hline - midwife & 0.0000 & 0.0000 & 0.0000 & 0.0000 \\
\hline - nurse & 0.0410 & 0.0471 & 0.1122 & 0.1804 \\
\hline - other professional & 0.0324 & 0.0520 & 0.0374 & 0.0371 \\
\hline - pharmacist & 0.0018 & 0.0024 & 0.0034 & 0.0027 \\
\hline - doctor & 0.3973 & 0.3655 & 0.2449 & 0.1936 \\
\hline \multicolumn{5}{|c|}{ Manager gender } \\
\hline - male & 0.8527 & 0.8154 & 0.8878 & 0.9045 \\
\hline - female & 0.1473 & 0.1846 & 0.1122 & 0.0955 \\
\hline Overtime & 176.7223 & 98.6190 & 88.6755 & 71.9570 \\
\hline
\end{tabular}


The impact of female managers on the gender pay gap was statistically significant at a level of 1 per cent. This means that we can confirm the hypothesis that female managers tend to better evaluate female subordinates in comparison to male managers.

The other step was the use of matching as pre-processing. The matching procedure was applied using the following characteristics: age, working time, years in firm, occupation, level of education, over time, sick leave and department. The manager gender was omitted as it was already reflected in the departments. Using nearest neighbour matching we received a sample of 3,272 employees, of which 1,636 were women and 1,636 men. Using coarsened exact matching led to a greater loss of data, as after the matching procedure only a sample of 671 employees remained, of which 377 were women and 294 men. The average characteristics of men and women after matching are shown in Table 4. The matching enabled to create a more homogenous sample of men and women.

The coefficients of the wage functions, estimated from the samples after matching, are shown in third and the fourth column of Table 3. In the case of nearest neighbour matching, the unexplained gender pay gap was 0.124 . The effect of women managers was positive on the wage of subordinates and negative on the gender pay gap. The fact that the employee had a women head of department reduced the wages of men in relation to women by 4.5 per cent. Also in this case, the effect of female managers on the gender pay gap was statistically significant. When using coarsened exact matching as pre-processing, the unexplained part of the gender pay gap decreased by 0.10 and both effects, the impact of women managers on earnings and on the gender pay gap, was negative. Having a female head of department decreased the gender pay gap by 5.4 percentage points. But it was not statistically significant. These results must be taken into account with caution due to the small sample of employees after coarsened exact matching, with only 97 female headed employees.

\section{Average treatment effect on the treated}

We used an alternative method to find out whether the gender of the manager influences the unexplained gender pay gap. We estimated the average treatment effect on the treated for men and women led employees. Firstly, using the least square method we estimated the ATT from the entire sample without matching. We estimated the wage functions of male employees (separately for men working in departments with a female head and for men working in departments with male heads). The result is shown in Table A1. We then calculated the average treatment effect on the treated from equation 6 using simulation in Zelig and the difference between the gender pay gap of male and female headed departments. The result is shown in Table 5.

The ATT was 0.0127 for female led employees and -0.0383 for male led employees. This means that women working in the departments headed by women received about a 1.27 per cent higher wage than men working in these departments and this wage difference could not be explained by different known characteristics of men and women. This result implies there is no discrimination against women. Conversely, it indicates low wage discrimination against men. But we must accept these results with caution as the estimated ATT was not statistically significant. On the other hand, women employed in the departments headed by men, were given a wage of about 3.83 per cent less than men due to their gender. The difference in the gender pay gap in male and female led departments was about 5.1 percentage points. 
Table 5

Average Treatment Effect on the Treated

\begin{tabular}{|l|c|c|c|c|c|}
\hline & $\begin{array}{c}\text { Female } \\
\text { manager }\end{array}$ & N & $\begin{array}{c}\text { Male } \\
\text { manager }\end{array}$ & N & Difference \\
\hline Without matching & $\begin{array}{c}0.0127 \\
(0.0352)\end{array}$ & 1,596 & $\begin{array}{c}-0.0383^{*} \\
(0.0183)\end{array}$ & 7,066 & $\begin{array}{c}-0.051^{*} \\
(0.0007)\end{array}$ \\
\hline Nearest neighbour & $\begin{array}{c}-0.0664^{*} \\
(0.0157)\end{array}$ & 482 & $\begin{array}{c}-0.1329^{*} \\
(0.0077)\end{array}$ & 2,790 & $\begin{array}{c}-0.0665^{*} \\
(0.0007)\end{array}$ \\
\hline matching & $\begin{array}{l}-0.0519 \\
(0.036)\end{array}$ & 97 & $\begin{array}{c}-0.0782^{*} \\
(0.0169)\end{array}$ & 599 & $\begin{array}{c}-0.0263^{*} \\
(0.0030)\end{array}$ \\
\hline
\end{tabular}

*significant at the 5 per cent level, standard error in brackets

When assessing the gender pay gap we must take into account that not all the characteristics of the male and female employees in the hospital were known and quantifiable. This implies that a part of the gender wage gap can be explained for example by more talent or work commitment of men. The conclusion can also be partially distorted by too many differences in the characteristics of men and women in the sample. To mitigate the effect of the latter problem, we used matching as pre-processing. We applied nearest neighbour matching and coarsened exact matching the same way as in the case of the wage function estimation.

Using nearest neighbour matching the ATT was negative for both groups of departments, male and female headed. But the unexplained gender pay gap was distinctly lower for the group of departments headed by women. The difference between the gender pay gaps of male and female headed departments was -0.0665. Having a female head of department decreased the gender pay gap by almost 6.7 percentage points. The ATT was in both cases statistically significant and the difference was statistically significant too.

Finally, we used coarsened exact matching to select subsamples of men and women with the most similar characteristics. The ATT reached values -0.0519 for female headed departments and -0.0782 for male headed departments. Also when using nearest neighbour matching, the ATT was negative for both groups of departments. Again, the unexplained gender pay gap was lower in the departments led by women. The women headed departments showed lower values of the gender pay gap by 2.6 percentage points.

To receive detailed results we calculated the ATT separately for groups of departments formed according to the proportion of female employees in the individual departments. In accordance with Cardoso and Winter-Ebmer (2010) findings, the impact of the female leaders on the male and female wage decreases with the higher proportion of women in the firm. We divided the departments into four groups. The first group covers departments with 20-40 per cent of female employees, the second group departments with 40-60 per cent, the third group departments with 60-80 per cent and the last group departments with 80-99.9 per cent of female employees. The ATT for each group is calculated in the same way as in the case of estimating the ATT for men and women headed departments. Because of the small number of employees in the case of coarsened exact matching, we did not estimate the wage function for men for the individual groups (equation 4) to estimate the potential wage of women if they were men. Instead of this, we used the wage functions of male employees 
after coarsened exact matching. This means we applied the same wage functions as we used for the calculation the ATT for men and women controlled departments.

Firstly, we calculated the ATT without matching and then we used nearest neighbour matching and coarsened exact matching as pre-processing. Table 6 shows the results.

Table 6

ATT for Individual Groups by Percentage of Women Employees

\begin{tabular}{|c|c|c|c|c|c|}
\hline Groups & $\begin{array}{l}\text { Female } \\
\text { manager }\end{array}$ & $\mathbf{N}$ & Male manager & $\mathbf{N}$ & Difference \\
\hline \multicolumn{6}{|c|}{ Without matching } \\
\hline 20-40 per cent of women & $\begin{array}{c}0.0731 \\
(0.1532)\end{array}$ & 44 & $\begin{array}{c}-0.0323^{*} \\
(0.0153)\end{array}$ & 665 & $\begin{array}{l}-0.1054^{*} \\
(0.0094)\end{array}$ \\
\hline 40-60 per cent of women & $\begin{array}{l}0.1698^{*} \\
(0.0323) \\
\end{array}$ & 64 & $\begin{array}{c}-0.1285^{*} \\
(0.0268) \\
\end{array}$ & 458 & $\begin{array}{c}-0.2983^{*} \\
(0.0054) \\
\end{array}$ \\
\hline $60-80$ per cent of women & $\begin{array}{l}-0.0551 \\
(0.1170)\end{array}$ & 256 & $\begin{array}{l}-0.1265^{*} \\
(0.0354)\end{array}$ & 1,607 & $\begin{array}{l}-0.0714^{*} \\
(0.0042)\end{array}$ \\
\hline 80-99.9 per cent of women & $\begin{array}{c}0.0563 \\
(0.0487)\end{array}$ & 1,232 & $\begin{array}{l}-0.0063 \\
(0.0322)\end{array}$ & 4,336 & $\begin{array}{c}-0.0626^{*} \\
(0.0012)\end{array}$ \\
\hline \multicolumn{6}{|c|}{ Nearest neighbour matching } \\
\hline 20-40 per cent of women & $\begin{array}{c}-0.0374 \\
(0.4044)\end{array}$ & 24 & $\begin{array}{l}-0.0313 \\
(0.0165)\end{array}$ & 626 & $\begin{array}{c}0.0061 \\
(0.0225)\end{array}$ \\
\hline 40-60 per cent of women & $\begin{array}{l}0.1588^{*} \\
(0.0376)\end{array}$ & 58 & $\begin{array}{c}-0.1006^{*} \\
(0.0241)\end{array}$ & 388 & $\begin{array}{c}-0.2594^{*} \\
(0.0052)\end{array}$ \\
\hline $60-80$ per cent of women & $\begin{array}{l}-0.0778 \\
(0.0445)\end{array}$ & 146 & $\begin{array}{l}-0.1335^{*} \\
(0.0194)\end{array}$ & 768 & $\begin{array}{l}-0.0557^{*} \\
(0.0032)\end{array}$ \\
\hline 80-99.9 per cent of women & $\begin{array}{l}-0.0535^{*} \\
(0.0248)\end{array}$ & 202 & $\begin{array}{c}-0.1147^{*} \\
(0.0119)\end{array}$ & 930 & $\begin{array}{l}-0.0612^{*} \\
(0.0016)\end{array}$ \\
\hline \multicolumn{6}{|c|}{ Coarsened exact matching } \\
\hline $20-40$ per cent of women & $\begin{array}{l}0.5577^{*} \\
(0.0957)\end{array}$ & 5 & $\begin{array}{l}-0.2493^{*} \\
(0.0266)\end{array}$ & 127 & $\begin{array}{l}-0.807^{*} \\
(0.0207)\end{array}$ \\
\hline 40-60 per cent of women & - & 0 & $\begin{array}{l}-0.0872^{*} \\
(0.0340)\end{array}$ & 152 & - \\
\hline $60-80$ per cent of women & $\begin{array}{l}-0.1125 \\
(0.1642) \\
\end{array}$ & 11 & $\begin{array}{c}0.0903 \\
(0.1160)\end{array}$ & 68 & $\begin{array}{l}0.2028^{*} \\
(0.0536)\end{array}$ \\
\hline 80-99.9 per cent of women & $\begin{array}{c}0.0040 \\
(0.0427)\end{array}$ & 68 & $\begin{array}{l}-0.0157 \\
(0.0332)\end{array}$ & 203 & $\begin{array}{l}-0.0197^{*} \\
(0.0065)\end{array}$ \\
\hline
\end{tabular}

*significant at the 5 per cent level, standard error in brackets

The unexplained gender pay gap was only with a few exceptions lower in the women headed departments. The ATT was very similar (about 3 per cent) for the group with 20-40 per cent of female employees after using nearest neighbour matching as pre-processing and significantly higher for female headed departments in the group with 60-80 per cent of female employees after using coarsened exact matching. But these results were not statistically significant.

Figure 3 illustrates the difference in the ATT calculated for male and female headed departments. The difference in the ATT calculated for male and female headed departments 
without matching and using nearest neighbour matching was minor. In both cases the women headed departments had a lower unexplained gender pay gap (differences were negative). In the group with 40-60 per cent of female employees, the difference in ATT for male and female headed departments was about -30 percentage points, in the departments with 60-80 and 80-99.9 per cent of female employees about -6 percentage points. The divergent differences in the ATT were visible in the department with 20-40 per cent of female employees, where this was -11 percentage points for the ATT calculated without matching and about 1 percentage point for the ATT estimated after nearest neighbour matching. The cause of these differences could be due to a relatively low sample of employees in this group. The results received for coarsened exact matching are strongly different. Using coarsened exact matching enabled to create a closely comparable sample of men and women. But it led to a large loss of data and to having a very small number of employees in the individual groups. Due to this the results have limited validity in this case.

Figure 3

Difference in ATT for Male and Female Headed Departments

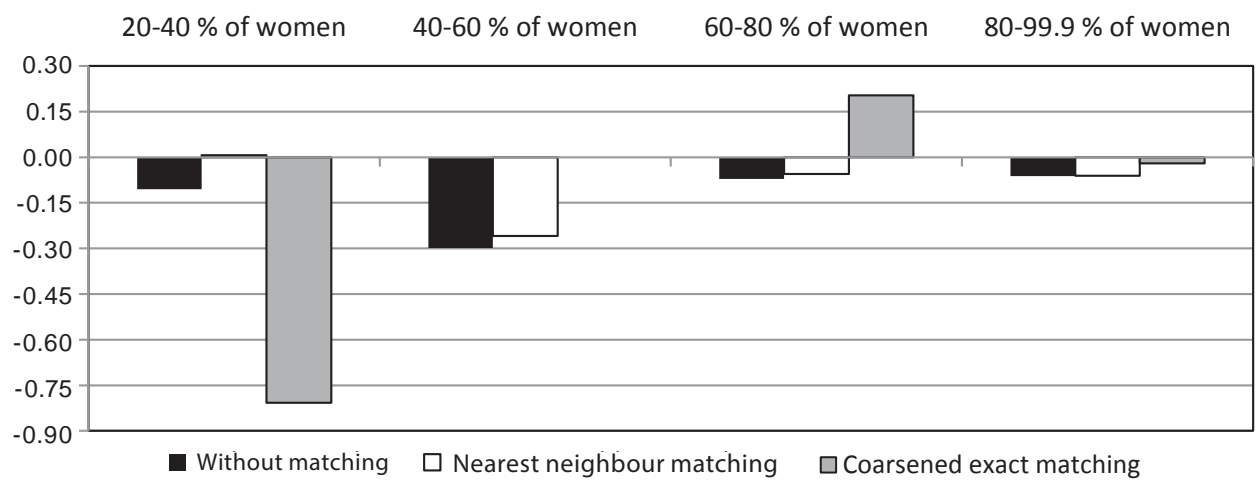

The results observed for the four different groups of departments confirmed the hypothesis, that women in leadership have a lower tendency to apply wage discrimination against women than men. We can see a tendency that the difference in the gender pay gap between male and female heads of departments narrows with a higher proportion of women in the department.

\section{Discussion and Conclusion}

The aim of this article was to consider the effect of the gender characteristics of middle managers on the wage of rank-and-file employees using a variation within a firm and to find out whether women in leadership show a lower tendency to use wage discrimination against women. We used administrative data from two Czech hospitals. The gender pay gap calculated as the difference between the logarithm of the average gross hourly earnings of male employees and female employees was 0.14 (14 per cent). Women received on average about 87 per cent of the male wage. In our hospitals, women led 32 per cent of the departments and women headed departments had a lower gender pay gap. 
To consider the effect of the female head of departments on the gender pay gap, we estimated the Mincer-type wage function of employees with a dummy for men, the female manager and the interaction of these two variables. The estimated gender pay gap of the complete sample reached about 12 per cent. The analysis suggests that having a female head of department caused a decrease in the gender pay gap by 6.18 percentage points. We used matching to get a more homogenous sample of male and female employees and to reduce bias and model dependency. When using matching as pre-processing, the effect of the female middle managers on the gender pay gap was also negative but slightly weaker.

We then used another method to confirm these findings - the average treatment effect on the treated estimation. We calculated the ATT separately for male and female headed departments and compared this identifying the unexplained gender pay gaps. We found that women, working in departments headed by women, received about a 1.27 per cent higher wage than men working in these departments and this wage difference could not be explained by different known characteristics of men and women. On the other hand, women employed in the departments headed by men received about a 3.83 per cent lower wage than men due to their gender. Among employees under female middle managers, the gender pay gap was about 5.1 percentage points lower compared to the employees with male middle managers.

The findings after using the matching procedure were similar. The unexplained gender pay gap was distinctly lower for the employees headed by women using nearest neighbour matching and coarsened exact matching as pre-processing. In the first case, the unexplained gender pay gap was about 6.7 percentage points lower for the group of departments headed by women and in the latter case about 2.6 percentage points.

Finally, we calculated the ATT for four different groups of departments defined by the proportion of female employees in the individual departments. There were only a few exceptions where the unexplained gender pay gap was not lower in the women headed departments. The difference between the male and female headed departments showed a tendency to decrease with the higher proportion of women in the departments.

Hultin and Szulkin (1999 and 2003), Cohen and Huffman (2007) and the study by Cardoso and Winter-Ebmer (2010) concluded that the gender wage gap reduced with a greater representation of women in management. Our findings are consistent with these.

We concluded that having a female middle manager led to a decrease in the gender pay gap of rank-and-file employees. The unexplained gender pay gap was lower among the employees under female middle managers and the effect of female managers on the wage was not negligible. The presence of a female head of department led to a decrease of the unexplained gender pay gap by almost 7 percentage points when compared to the male headed departments. As we use for our analysis firms in the public sector, where the wages are subject to specific government regulation, it can be expected that an analysis of the private sector would show an even stronger influence. These findings allow us to confirm the hypothesis that women in leadership have a lower tendency to apply wage discrimination against women than male managers. 


\section{References}

Bertrand, M., Hallock, K. (2001), "The Gender Gap in Top Corporate Jobs." Industrial and Labour Relations Review, Vol. 55, No. 1, pp. 1-21.

Cardoso, A. R, Winter-Ebmer, R. (2010), "Female-Led Firms and Gender Wage Policies." Industrial and Labour Relations Review, Vol. 64, No. 1, pp. 143-163.

Cohen, P., Huffman, M. (2007), "Working for the Woman? Female Managers and the Gender Wage Gap." American Sociological Review, Vol. 72, No. 5, pp. 681-704.

Ho, D. E., Imai, K., King, G., Stuart, E. A. (2007), "Matching as Nonparametric Preprocessing for Reducing Model Dependence in Parametric Causal Inference." Political Analysis, Vol. 15, No. 3, pp. 199-236.

Hultin, M., Szulkin, R. (1999), "Wages and Unequal Access to Organizational Power: An Empirical Test of Gender Discrimination." Administrative Science Quarterly, Vol. 44, No. 3, pp. 453-472.

Hultin, M., Szulkin, R. (2003), "Mechanisms of Inequality Unequal Access to Organizational Power and the Gender Wage Gap." European Sociological Review, Vol. 19, No. 2, pp. 143-159.

lacus, S. M., King, G., Porro, G. (2012), “Causal Inference without Balance Checking: Coarsened Exact Matching." Political Analysis, Vol. 20, No. 1, pp. 1-24.

Jurajda, S., Paligorová, T. (2009), "Czech Female Managers and their Wages." Labour Economics, Vol. 16, No. 3, pp. 342-351.

Jurajda, S. (2005), "Gender Segregation and Wage Gap: an East-West Comparison." Journal of the European Economic Association, Vol. 3, No. 2-3, pp. 598-607.

King, G., Tomz, M., Wittenberg, J. (2000), "Making the Most of Statistical Analyses: Improving Interpretation and Presentation. "American Journal of Political Science, Vol. 44, No. 2, pp. 341-355.

Mincer, J. (1974), Schooling, Experience and Earnings. New York: NBER Press.

Oaxaca, R. (1973), "Male-female Wage Differentials in Urban Labour Markets." International Economic Review, Vol. 14, No. 3, pp. 693-709.

Plantenga, J., Remery, C. et al. (2006), The Gender Pay Gap. Origins and Policy Responses. A Comparative Review of Thirty European Countries. Luxembourg: Office for Official Publications of the European Communities.

Shin, F. (2012), "The Gender Gap in Executive Compensation: The Role of Female Directors and Chief Executive Officers." The ANNALS of the American Academy of Political and Social Science, Vol. 639, No. 1, pp. 258-278.

Stupnytskyy, O. (2007), Struktura rozdílů ve výdělcích mužů a žen v managementu. Prague: VúPSV.

Tajfel, H., Turner, J. C. (1979), "An Integrative Theory of Intergroup Conflict," in W. G. Austin, W. G. \& Worchel, S., ed., The Social Psychology of Intergroup Relations. Monterey, CA: Brooks-Cole, pp. 33-47.

Tajfel, H. (1982), "Social Psychology of Intergroup Relations." Annual Review of Psychology, Vol. 33, No. 1, pp. 1-39.

Vlach, J., Šnajdrová, Z., Kozelský, T., Musil, J. (2008), Gender v managementu. Prague: VúPSV.

Wooldridge, J. (2002), Econometric Analysis of Cross Section and Panel Data. Cambridge: MIT Press. 


\section{Appendix}

Table A1. Men wage functions for ATT calculation

\begin{tabular}{|c|c|c|c|c|}
\hline & \multicolumn{2}{|c|}{$\begin{array}{c}\text { Without matching and nearest } \\
\text { neighbour matching }\end{array}$} & \multicolumn{2}{|c|}{ Coarsened exact matching } \\
\hline & $\begin{array}{l}\text { Female } \\
\text { manager }\end{array}$ & Male manager & $\begin{array}{l}\text { Female } \\
\text { manager }\end{array}$ & Male manager \\
\hline Constant & $\begin{array}{c}3.9887^{* * *} \\
(0.3800)\end{array}$ & $\begin{array}{c}3.4510^{* * *} \\
(0.1111)\end{array}$ & $\begin{array}{c}3.4365^{* * *} \\
(0.9679)\end{array}$ & $\begin{array}{c}3.0048^{* * *} \\
(0.3749)\end{array}$ \\
\hline Age & $\begin{array}{c}0.0308^{* * *} \\
(0.0094)\end{array}$ & $\begin{array}{c}0.0443^{* * *} \\
(0.0041)\end{array}$ & $\begin{array}{l}0.0595 \\
(0.0448)\end{array}$ & $\begin{array}{c}0.0379 * * * \\
(0.0117)\end{array}$ \\
\hline Age squared & $\begin{array}{l}-0.0003 * * * \\
(0.0001)\end{array}$ & $\begin{array}{c}-0.0004 * * * \\
(0.0000)\end{array}$ & $\begin{array}{l}-0.0008 \\
(0.0005)\end{array}$ & $\begin{array}{l}-0.0003^{* *} \\
(0.0001)\end{array}$ \\
\hline Working time & $\begin{array}{l}-0.2106^{* *} \\
(0.0927)\end{array}$ & $\begin{array}{c}-0.1176^{* * *} \\
(0.0332)\end{array}$ & $\begin{array}{c}0.2553 \\
(0.5264)\end{array}$ & $\begin{array}{l}-0.0627 \\
(0.1326)\end{array}$ \\
\hline Years in firm & $\begin{array}{l}0.0125^{* * *} \\
(0.0027)\end{array}$ & $\begin{array}{c}0.0077^{* * *} \\
(0.0010)\end{array}$ & $\begin{array}{l}0.0060 \\
(0.0149)\end{array}$ & $\begin{array}{l}0.0099 * * * \\
(0.0032)\end{array}$ \\
\hline \multicolumn{5}{|l|}{ Occupation } \\
\hline - technical and economic worker & $\begin{array}{c}0.0103 \\
(0.2372)\end{array}$ & $\begin{array}{c}0.3723^{* * *} \\
(0.0346)\end{array}$ & $\begin{array}{l}-0.3878 \\
(0.5401)\end{array}$ & $\begin{array}{l}0.1949^{* *} \\
(0.0828)\end{array}$ \\
\hline - orderly & $\begin{array}{l}-0.0196 \\
(0.2139)\end{array}$ & $\begin{array}{l}-0.0860 \\
(0.0620)\end{array}$ & $\begin{array}{l}-0.2244 \\
(0.4383)\end{array}$ & $\begin{array}{c}0.4281 \\
(0.2889)\end{array}$ \\
\hline - lower medical worker & $\begin{array}{c}0.2220 \\
(0.2406)\end{array}$ & $\begin{array}{c}0.2912^{* * *} \\
(0.0885)\end{array}$ & $\begin{array}{l}-0.2858 \\
(0.3970)\end{array}$ & $\begin{array}{l}0.5968^{*} \\
(0.3110)\end{array}$ \\
\hline - paramedical worker & $\begin{array}{c}0.2227 \\
(0.2656) \\
\end{array}$ & $\begin{array}{c}0.2229 * * * \\
(0.0731)\end{array}$ & $\begin{array}{l}-0.8905^{*} \\
(0.4620) \\
\end{array}$ & $\begin{array}{c}0.3941 \\
(0.3067) \\
\end{array}$ \\
\hline - medical laboratory technician & $\begin{array}{c}0.2270 \\
(0.2920)\end{array}$ & $\begin{array}{c}0.2531^{* * *} \\
(0.0917)\end{array}$ & $\begin{array}{l}-0.2537 \\
(0.4471)\end{array}$ & $\begin{array}{c}0.5196 \\
(0.3196) \\
\end{array}$ \\
\hline - pharmaceutical assistant & - & $\begin{array}{l}-0.0276 \\
(0.2534) \\
\end{array}$ & - & $\begin{array}{c}0.4334 \\
(0.3882) \\
\end{array}$ \\
\hline - midwife & - & - & - & - \\
\hline - nurse & $\begin{array}{l}0.2780 \\
(0.2415)\end{array}$ & $\begin{array}{c}0.3492^{* * *} \\
(0.0690)\end{array}$ & $\begin{array}{l}-0.3267 \\
(0.2848)\end{array}$ & $\begin{array}{l}0.6053^{* *} \\
(0.2800)\end{array}$ \\
\hline - other professional & $\begin{array}{c}0.2940 \\
(0.2589) \\
\end{array}$ & $\begin{array}{c}0.2910^{* * *} \\
(0.0675)\end{array}$ & $\begin{array}{l}-0.2063 \\
(0.2915) \\
\end{array}$ & $\begin{array}{l}0.4872^{*} \\
(0.2796)\end{array}$ \\
\hline - pharmacist & $\begin{array}{l}0.7122^{* *} \\
(0.2905)\end{array}$ & $\begin{array}{c}0.1672 \\
(0.2616)\end{array}$ & $\begin{array}{l}0.3489 \\
(0.3132)\end{array}$ & - \\
\hline - doctor & $\begin{array}{l}0.4393^{*} \\
(0.2415) \\
\end{array}$ & $\begin{array}{l}0.5143^{* * *} \\
(0.0618)\end{array}$ & - & $\begin{array}{l}0.4676^{*} \\
(0.2589) \\
\end{array}$ \\
\hline \multicolumn{5}{|l|}{ Education } \\
\hline $\begin{array}{l}\text { - upper secondary - vocational } \\
\text { without certificate }\end{array}$ & $\begin{array}{l}-0.1763 \\
(0.2162)\end{array}$ & $\begin{array}{l}-0.1462 \\
(0.1694)\end{array}$ & - & - \\
\hline $\begin{array}{l}\text { - upper secondary - vocational } \\
\text { certificate }\end{array}$ & $\begin{array}{l}-0.0209 \\
(0.0543)\end{array}$ & $\begin{array}{l}0.0684^{* *} \\
(0.0326)\end{array}$ & - & $\begin{array}{l}0.1721^{* *} \\
(0.0687)\end{array}$ \\
\hline
\end{tabular}




\begin{tabular}{|l|c|c|c|c|}
\hline $\begin{array}{l}\text { - upper secondary - school } \\
\text { diploma }\end{array}$ & $\begin{array}{c}0.0270 \\
(0.0690)\end{array}$ & $\begin{array}{c}0.0976^{* * *} \\
(0.0364)\end{array}$ & $\begin{array}{c}0.1203 \\
(0.2166)\end{array}$ & $\begin{array}{c}0.2444^{* * *} \\
(0.0871)\end{array}$ \\
\hline $\begin{array}{l}\text { - tertiary - higher professional } \\
\text { education }\end{array}$ & $\begin{array}{c}-0.0412 \\
(0.1159)\end{array}$ & $\begin{array}{c}0.1591^{* * *} \\
(0.0574)\end{array}$ & $\begin{array}{c}0.2162 \\
(0.3032)\end{array}$ & $\begin{array}{c}0.2895^{* *} \\
(0.1201)\end{array}$ \\
\hline - tertiary - bachelor level & $\begin{array}{c}0.1778^{*} \\
(0.1014)\end{array}$ & $\begin{array}{c}0.1872^{* *} \\
(0.0777)\end{array}$ & $\begin{array}{c}0.2889 \\
(0.2380)\end{array}$ & $\begin{array}{c}0.2820 \\
(0.1743)\end{array}$ \\
\hline - tertiary - master and doctoral & $\begin{array}{c}0.0648 \\
\text { level }\end{array}$ & $\begin{array}{c}0.2807^{* * *} \\
(0.0484)\end{array}$ & $\begin{array}{c}0.4213^{* *} \\
(0.1873)\end{array}$ & $\begin{array}{c}0.5812^{* * *} \\
(0.1164)\end{array}$ \\
\hline Overtime & $\begin{array}{c}0.0003^{*} \\
(0.0001)\end{array}$ & $\begin{array}{c}0.0003^{* * *} \\
(0.0000)\end{array}$ & $\begin{array}{c}0.0001 \\
(0.0012)\end{array}$ & $\begin{array}{c}0.0006^{* * *} \\
(0.0001)\end{array}$ \\
\hline Sick leave & -0.0001 & 0.00001 & $0.0138^{* *}$ & 0.0002 \\
\hline Departments & $(0.0002)$ & $(0.0001)$ & $(0.0055)$ & $(0.0004)$ \\
\hline $\mathbf{R}^{2}$ & Yes & Yes & Yes & Yes \\
\hline N & 0.6817 & 0.7864 & 0.8754 & 0.7401 \\
\hline
\end{tabular}

***significant at the 1 per cent level, ${ }^{* *}$ significant at the 5 per cent level, ${ }^{*}$ significant at the 10 per cent level, standard error in brackets 